\title{
HVORFOR KOM N. F. S. GRUNDTVIG IKKE I VIBORG LATINSKOLE?
}

\author{
Af F. Paludan-Müller.
}

Det er almindelig kendt, at Grundtvig 9 år gammel måtte forlade sit hjem i Udby Præstegaard i Sydsjælland og drage til Thyregod vest for Vejle for at undervises og forberedes til latinskolen af sognepræsten, Laurids Feld, som havde været huslærer i Udby. Grundtvigs ældste broder, Otto, blev student fra Herlufsholm. De to næste brødre i rækken, Jacob Ulrik Hansen Grundtvig og Niels Christian Bang Grundtvig, fulgte med deres lærer, Laurids Feld, da han blev præst på Hirtsholmene. Der forberedtes de i tre år, og det var så meningen, at de, som Otto, skulle have været herlovianere. Men det glippede, og de optoges da i Viborg Latinskole. Laurids Feld var en præstesøn fra Vammen ved Viborg, var ganske vist selv dimitteret fra Aalborg, men brødre af ham havde gået $\mathrm{i}$ Viborg Latinskole, som forøvrigt på den tid havde et godt navn. Jacob blev student 1795, Niels 1796. Da nu deres lillebror, Frederik, efter 6 års forberedelse af Laurids Feld, som 1791 var blevet forflyttet til Thyregod, 1798 var moden til latinskolen, optoges han i Aarhus Latinskole. Hvorfor valgtes Viborg ikke? Det kan skyldes, at Laurids Feld og Frederiks forældre af os ukendte grunde har følt sig tiltrukket af Aarhus Latinskole. Men har Viborg ikke stødt fra? Hvordan var de erfaringer, som var gjort med Jacob og Niels i Viborg?

I »Fortegnelse over Viborg Skole Disciple« skriver Rektor Hansen: 》) Jacob Ulrik Hansen Grundtvig, fød i Odden Præstegaard i Sjælland 1775 - Faderen Hr. Johan Grundtvig, Sognepræst i benævnte Odden; siden forflyttet til Udbye ved Vordingborg - Moderen Cathrina Maria Bang - blev d. 1. Novbr. 1791 ansat her i 5te Lectie med nogenledes grunde i Latin og Grædsk - 1793 opfløttet i Mester L.: Syntes stiv i Sindelag, og ikke nogen ordentlig Videnskabs Lærling - var med N: Lillel. Hansen /: vid. P. seq. / ( $\mathrm{s}$ : se følg. side) $\mathrm{i}$ at overfalde og slaae nogle af sine Meddisciple d. 6. Octbr. 1794 - blev følgende dag sat publice til Rette (i alle Skole Læreres og hele Skolens Overværelse) og skulde have været rævset; men viste sig derimod gjenstridig og under uartige Udtryk gik bort - kom følgende Dag og bad om Forladelse og tilbød sig at give hvilken Fyldestgørelse, som maatte vorde paalagt - Af Medlidenhed, og for at forskaane en fraværende Fader for Sorg, antog man ham da igen, efter at han midt i Skolen havde erklæret afbigt, og Forbedring, og der med Haandtager (slag i hånden) var rævset 
for den offentlige Forløbelse, og siden i Lectien for den private Fornærmelse -

Om den medskyldige hedder det: „Niels Lillelund Hansen .................. blev ansat her i 4. Lectie 1791 d. 2. Novbr. ................... 1794 d. 6. oct. havde han ved et Bolspil fornærmet sine Medspillere (Meddisciple) ved modvillig ( $\supset$ : drilagtig) at bortkaste deres Bol, og derpaa, efter en Ordkrig, voldsomt anfaldet og slaget dem; efter holdet Forhør først privatim, siden publice, blev han følgende Dag revset med Riis, og alvorligen advaret imod saadan usømmelig Opførsel, hvortil han efter forgangen adfærd syntes tilbøjelig og undsagt med større straf eller Skole-Forviisning, om han nogensinde mere gjorde sig skyldig i denne eller anden den lignende Forbrydelse - Efter at han efter Examen artium, philosoph. et philolog. havde udmærket sig ved et godt Forhold og megen Flid, paakom ham stor Sindssvaghed, som hindrede ham $i$ at tage latinsk-jurid. Examen, til hvilken han var moden, og som han vist med stort Held skulle have faaet - han døde her i Byen, som Sinds- og legems-svag i Januar 1800.«

Som regel er elevens videre skæbne, således som her, fortalt med få ord i discipelfortegnelsen. Imidlertid er det ikke tilfældet med Jacob Grundtvig. Det er ikke engang oplyst, at han blev student. Det må vi til eksaminationsprotokollerne for at se. Skolen dimitterede ham 7. september 1795 som $\mathrm{nr} .8$ af 8 med en tynd eksamen.

Om broderen skrives der i discipelfortegnelsen:

»Niels Christian Bang Grundtvig fød i Udbye Præstegaard i Sjælland Aa: 1777: iøvrigt lige med hans ommeldte Broder - opflyttet i Mesterleclectien 1794 (NB: som Privatist) blev 1796 d. 20. Juli, efter Faderens Begjæring af S.T. ( $\supset$ : Salvo Titulo) hr. Feldt i Thyregod affordret - og afskediget med Skudsmaal: at han fra 1ste Novbr. 1791 havde publice ( 0 : som almindelig elev) freqventeret Skolen indtil Septbr. 1794, da han udgangen fra den publique Anførsel (o: Undervisning), efter Begjering, som Privatist, for at følge sin ældre Broder blev antaget $i$ den øverste Lectie, hvortil han ellers af Mangel paa Flid ikke var duelig, og der siden baade af hr. Kruse (Konrektor) og mig gratuito undervist - Naar undtages Efterladenhed og Bortebliven fra Skolen, hvilken Fejl han dog tilsidst syntes at ville have arbejdet sig løs fra - har iøvrigt hans opførsel været ustraffelig - det vil stedse glæde mig, baade for hans agtværdige hr. Faders Skyld og for hans eget Vel, at han under opvakt Flid, blive ( 0 : må blive) til en arbejdsom, duelig og lykkelig akademist og politisk Borger. - NB. dette Skudsmaal efter Begjxring indeholdt ( $\mathrm{O}$ : holdt tilbage) - og efter længere Prøve dimitteret til Acad. (॰: Akademiet, altså Universitetet)«. Nogen smuk fremgang har han altsaa heller ikke haft i Viborg Latinskole, trods de gode evner, skolen andet sted skriver om. Det ser mærkeligt ud, at han kan optræde de to sidste år i skolen som privatist, men sligt var ikke sjældent. I samme klasse som Niels sad en privatist til; han nåede dog ikke at blive student. J. P. Mynster gik som privatist i Vor Frue Skole (Metropolitanskolen). Forholdet må have været det, at skolen ikke vedkendte sig noget ansvar for en privatist. Derfor kan privatistens værge også frabede sig skolens vidnesbyrd, hvad der - 
yderst forståeligt - sker i tilfældet med Niels. En privatist fik selvfølgelig heller ikke stipendium.

Skolens eksamensprotokol viser, at Niels som de andre dimittender måtte underkaste sig eksamen ved skolen $i$ alle fagene. Han fik en helt net eksamen, bedre end broderens, og dimitteredes 12. september 1796 til universitetet for der som de andre at underkaste sig den egentlige examen artium. Det endte altså ikke så galt. Men både i Thyregod og Udby må man gennem skolens vidnesbyrd og klager over dovenskab have haft et levende indtryk af lidet vellykket skolegang. Hertil kommer så den pinlige sag fra oktober 1794, da Jacob var på randen af udvisning og kun undgik den ved at underkaste sig en ydmygende straf. Han og Niels boede hos en enkeprovstinde Friis, og hun kan ikke have været uden kendskab til historien. Gennem hende, om ikke ad anden vej, har ihvert fald Laurids Feld fået oplysning. Hvorom alting er, man forstår, at sporene i Viborg har skræmt, og at en anden skole blev valgt for den yngste søn, da han et par år efter skulle $i$ den sorte skole. Det blev ikke Viborg Latinskole, han kom til at udgyde sine forbandelser over. Forøvrigt havde den som nævnt $i$ disse år et godt ry. Men en lille snes år tilbage var den i dybt forfald, præget af elevernes dovenskab, uduelighed og skamløse optøjer på gaden. Biskop Rottböll klager bittert over sin frugtesløse kamp mod fordærvelsen. Man forstår bedre den store strenghed, som skolen viste $\mathrm{i}$ boldspilsagen, ved at mindes denne ret nære fortid. Hvor bølleagtigt de to store drenge er faret frem mod kammeraterne, har vi desværre kun rektors korte omtale af.

De tre drenge, som her er omtalt, fik alle et kort liv. Niels Lillelund Hansen døde som nævnt, sindssyg, i januar 1800. Jacob Grundtvig blev cand. theol. og kom år 1800 som præst til Guineakysten. Han tog med kraft og alvor fat på sin gerning. Han lagde en stejl vilje for dagen, men også udpræget bravhed. Allerede september 1800 døde han. Han fik et godt eftermæle. Niels Grundtvig blev også cand. theol. og blev udnævnt til sin broders eftermand. Han kom til Guinea oktober 1802. Han kom snart ind i store stridigheder, viste også en stejl vilje, men, efter F. Rønnings dom tillige stor uretsindighed. Han synes at have lagt sig efter forretningsvæsen med fremgang og lagde også sit gode hoved for dagen ved sine spidsfindige indlæg $i$ stridighederne. Allerede foråret 1803 døde han. 